\title{
Detrimental effect of rutin on Anticarsia gemmatalis
}

\author{
Clara Beatriz Hoffmann-Campo ${ }^{(1)}$, José Augusto Ramos Neto(2), Maria Cristina Neves de Oliveira ${ }^{(1)}$ \\ and Lenita Jacob Oliveira ${ }^{(1)}$
}

\begin{abstract}
(1)Embrapa Soja, Caixa Postal 231, CEP 86001-970 Londrina, PR, Brazil. E-mail: hoffmann@cnpso.embrapa.br, mcneves@cnpso.embrapa.br, lenita@cnpso.embrapa.br (2)Hokko do Brasil Indústria Química e Agropecuária Ltda., Rua Jundiaí, 50, 9o andar, Paraíso, CEP 04001-904 São Paulo, SP, Brazil. E-mail: zeaugustoneto@uol.com.br
\end{abstract}

\begin{abstract}
Behavioral and nutritional effect of rutin (quercetin 3-O-rutinosídeo) on Anticarsia gemmatalis Hübner (Lep.: Noctuidae), a major soybean defoliator in Brazil, was evaluated from the thirdinstar to pupation. Rutin is one of the flavonol glycosides identified in the leaves of the wild soybean PI 227687. Larval weight and amount of ingested food decreased as rutin concentration in the diet increase. An interactive effect between feeding time and diet (treatment) was observed on insect growth; when larvae fed on pure-diet, feeding time elongation resulted in heavier pupae. Differently, the weight of larvae fed on rutin-diet remained almost stable, in spite of eating for longer. A. gemmatalis growth was negatively influenced by rutin-diet not only by feeding deterrence but also by post-ingestive effect on insect growth, since after adjustment of pupal weight by the amount of ingested food (covariate), the effect of diet remained significant. Rutin negatively influenced A. gemmatalis growth as result of pre-ingestive effect, indicated by reduction in food consumption, and post-ingestive effect, indicated by lower conversion of ingested food into body mass and food assimilation.
\end{abstract}

Index terms: Glycine max, feeding deterrence, insect nutrition, flavonol glycoside, Lepidoptera.

\section{Efeito prejudicial de rutina em Anticarsia gemmatalis}

\begin{abstract}
Resumo - O efeito de dieta contendo rutina (quercetina 3-O-rutinosídeo) no comportamento e na nutrição do principal desfolhador da soja, Anticarsia gemmatalis Hübner (Lep.: Noctuidae) foi avaliado do terceiro ínstar até a formação da pupa. Rutina é um dos flavonóis glicosídicos identificados em folhas da soja selvagem PI 227687. O peso das lagartas e o consumo decresceram com o aumento na concentração de rutina na dieta. Houve interação entre o tempo de alimentação e a dieta no crescimento do inseto; lagartas alimentadas com dieta pura, cujo tempo de alimentação prolongou-se, originaram pupas mais pesadas. O peso das pupas alimentadas com dieta contendo rutina permaneceu estável, apesar do maior tempo de alimentação. Rutina afetou negativamente o crescimento do inseto, não somente pela inibição alimentar, mas também em conseqüência de eventos pósingestivos, já que depois do ajuste do peso de pupa pelo consumo (covariável), o efeito do tratamento permaneceu significativo. Assim, o efeito negativo de rutina em A. gemmatalis resulta de efeitos pré-ingestivos, indicados pela redução no consumo, e pós-ingestivos, indicados por baixas conversões do alimento ingerido em biomassa e assimilação de alimentos.
\end{abstract}

Termos para indexação: Glycine max, inibição alimentar, nutrição de insetos, flavonol glicosídico, Lepidoptera.

\section{Introduction}

The velvetbean caterpillar, Anticarsia gemmatalis Hübner, 1818 (Lep.: Noctuidae), is one of the most common soybean-defoliating insect and, if not properly controlled can cause significant losses in the crop yield in all Brazilian regions (Hoffmann-Campo et al., 2003).

In spite of the proven efficiency of biological control, through use of nucleopolyhedrovirus of the insect (AgMNPV) (Moscardi, 1999), and insect growth regulators (IGRs) (Corrêa-Ferreira et al., 2000), broad spectrum insecticides are still being used. To reduce the costs of production and negative environmental impacts in Brazil, efforts have been made to develop alternative methods to control A. gemmatalis and other soybean insect-pests. One of the alternative techniques is host plant resistance, which presents, among other advantages, practicality of use and safety.

Resistance to insects is mainly due to chemical substances (allelochemicals) present in the host plants, such as alkaloids, flavonoids, terpenoids, sterols, etc. (Kubo \& Hanke, 1986). Although the chemical 
importance of those substances has been recognized since early fifties, their use by the breeders has been little considered (Kogan, 1986). The identification of those substances, and their role in the plant-insect interactions, can help geneticists to keep them in the descending generations, to constitute part of the arsenal of plant defense.

In food preference test with $A$. gemmatalis, genotypes BR82-12547, IAC74-2832, PI 227687, PI 229358, PI 274454 were rejected by the caterpillars (HoffmannCampo et al., 1994). The effect of soybean genotypes in A. gemmatalis biology, consumption and food utilization was estimated (Oliveira et al., 1993); caterpillars fed on the resistant cultivar IAC-100 leaves presented longer larval development and smaller weight in relation to those fed on other tested materials.

Seven flavonoid glycosides were identified in soybean leaves of wild soybean plant introductions, as PI 227687 (Hoffmann-Campo, 1995), a genotype widely used in breeding programs as source of resistance to insects. Rutin (quercitin 3-O-rutinoside), one of these flavonoids, showed antibiotic and/or antifeeding effect in several defoliating insects such as Manduca sexta (L.) (Stamp \& Skrobola, 1993), Heliothis virescens (F.) (HoffmannCampo, 1995) and Trichoplusia ni (Hübner) (Hoffmann-Campo et al., 2001).

In fact, phenolics, as rutin and chlorogenic acid, are considered models in studies of plant antiherbivore defense (Bi et al., 1997). However, flavonol effects can vary depending on the insect specie and, frequently, monophagous and oligophagous insect, as A. gemmatalis, can use it to recognize their host plants (Harborne \& Grayer, 1993). Among soybean associated insects, $H$. virescens and $T$. ni are occasional pests and, only under certain conditions, can attack this plant (Kogan \& Turnipseed, 1987) and, thus, they are not usually exposed to its defense compounds.

The aglycone quercitin and rutin, one of its glycoside, increased mortality and elongated the larval period of A. gemmatalis (Gazzoni et al., 1997), although the nutritional and post-ingestive effect of such flavonol remains to be further investigated. Thus, as there are reasonable evidences that resistance of soybean PI 227687 comes from chemical compounds, mainly rutin (Hoffmann-Campo, 1995; Piubelli et al., 2005), the complete understanding of its effect on a main defoliator and soybean specialist pest A. gemmatalis behavior and nutrition is important to the success of chemically based breeding programs.
The objective of this work was to assess the behavioral and nutritional effects of rutin on A. gemmatalis.

\section{Material and Methods}

Experiments were carried out in the laboratory of Insect Plant Interactions and Phytochemistry of Embrapa (Empresa Brasileira de Pesquisa Agropecuária) in Londrina, $\mathrm{PR}$, to test the effect of rutin in A. gemmatalis survival, growth, and nutrition. The artificial diet (Hoffmann-Campo et al., 1985) was prepared in the micro-oven and when reaching $40^{\circ} \mathrm{C}$, the flavonoid was thoroughly mixed, and the diet was poured in rearing containers.

The newly hatched larvae, from Embrapa Soja massrearing laboratory, were clustered, maintained (to avoid neonate mortality caused by injury) in $110 \mathrm{~mL}$ paperwaxed cups, containing basic control artificial diet or in the same diet amended with 0.65 or $1.30 \%$ rutin. Concentrations were calculated based on dried weight of diet.

At the beginning of third instar, 30 larvae from each treatment were weighed and individually transferred to $30 \mathrm{~mL}$ acrylic cups (Fill-rite Corp. Newark, NJ) where they were maintained until pupal stage. The control or rutin-enriched diets were prepared and poured in plastic container (gerbox) and, when cooling down, cut in pieces and weighed. Bioassays were carried out in environmental chambers $\left(27 \pm 2^{\circ} \mathrm{C} ; 70 \pm 10 \% \mathrm{RH}\right.$; 14L:10D photophase).

The survival of larvae was daily checked and the pupae were weighed two days after pupation; feeding and development time were recorded and expressed in days. To estimate the initial dry weight of the larvae, five third-instar larvae were taken from each treatment, weighed, frozen $\left(-50^{\circ} \mathrm{C}\right)$, oven-dried $\left(60^{\circ} \mathrm{C}, 72\right.$ hours) and reweighed. The correction factor for larval fresh to dry weight was calculated. The values obtained were multiplied by the fresh weight of each set of experimental larvae. The same procedure was used to calculate the dry weight of the food. Pupae were frozen $\left(-50^{\circ} \mathrm{C}\right.$, 96 hours), and as the unconsumed food and egested products were oven dried $\left(50^{\circ} \mathrm{C}, 96\right.$ hours) and weighed.

The experiments were carried out in a completely randomized design, with 30 replicates. All data were analyzed using SAS (SAS Institute, 1996). The effect of diets with and without rutin (treatments) on pupal weight, amount of ingested food, egested products, and feeding time were analyzed through analysis of variance 
(ANOVA). Means were compared by least significant differences (LSD), when ANOVA, performed by the general linear model (GLM), indicated a significant effect of treatment $(\mathrm{p}<0.05)$.

Analysis of covariance (ANCOVA) (Raubenheimer \& Simpson, 1992), followed by bicoordinate plots (Raubenheimer \& Simpson, 1994) was used to remove the effect of covariate feeding time from weight of pupae (growth or performance) and amount of ingested food (consumption). The same statistical procedure was used to separate pre and post-ingestive effects of treatment (Horton \& Redak, 1993; Raubenheimer \& Simpson, 1994) on A. gemmatalis growth, when the differences in pupal weight and amount of egested food were adjusted for covariate consumption. After performing ANCOVA, if the interaction among the treatment and covariate was not significant, the parallel line model was used considering the main effect of treatment adjusted for covariate. When the effect of treatment was significant at least to $\mathrm{p} \leq 0.05$, means were compared by ANCOVA means (least square means).

\section{Results and Discussion}

ANOVA showed significant effect of diet on pupal weight and amount of ingested food (consumption), while the amount of egested products was not affected by adding rutin to the diet (Table 1). Pupal weight and consumption decreased as the rutin concentration increased in the diet, while feeding time was longer when larvae fed on the diet containing $1.30 \%$ rutin than in the other diets. Feeding for longer period but eating smaller amount of food, in each meal, probably was the strategy used by the insect to avoid toxicoxis. However, they did not avoid adverse effect on their growth. The insect growth (pupal weight) depended on an interactive effect

Table 1. Effect of rutin concentration on Anticarsia gemmatalis pupal weight, ingested food weight, egested food weight and feeding time, from third instar to prepupa stadium $^{(1)}$.

\begin{tabular}{ccccc}
\hline $\begin{array}{c}\text { Rutin } \\
(\%)\end{array}$ & \multicolumn{3}{c}{ Weight (mg) } & Feeding time \\
\cline { 2 - 4 } & Pupa & Ingested food & Egested food & (days) \\
\hline 0.00 & $63.32 \pm 1.40 \mathrm{a}$ & $264.23 \pm 10.14 \mathrm{a}$ & $142.39 \pm 8.15$ & $6.17 \pm 0.23 \mathrm{a}$ \\
0.65 & $53.82 \pm 1.27 \mathrm{~b}$ & $231.13 \pm 9.29 \mathrm{~b}$ & $138.53 \pm 7.41$ & $6.34 \pm 0.21 \mathrm{a}$ \\
1.30 & $49.72 \pm 1.37 \mathrm{c}$ & $188.23 \pm 9.93 \mathrm{c}$ & $158.69 \pm 7.98$ & $7.76 \pm 0.23 \mathrm{~b}$ \\
\hline F values & $23.63^{* * *}$ & $14.47^{* * *}$ & $1.87^{\mathrm{ns}}$ & $14.64^{* * *}$ \\
\hline
\end{tabular}

(1)Means $(\mathrm{N}=30)$ followed by the same letter in the column were not different

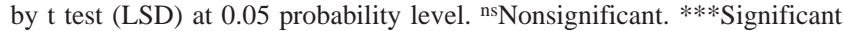
at $0.1 \%$ probability level. of feeding time and diet (Table 2). The response of insects feeding on control-diet (without rutin addition) to the extension of the feeding time was positive (Figure 1), i.e., increasing feeding time resulted in heavier

Table 2. ANCOVA testing for the effect of diets containing different concentration of rutin on the weight of pupa and weight of ingested food adjusted for feeding time, as covariate; on the weight of pupae and on the amount of egested food adjusted for amount of ingested food, as covariate.

\begin{tabular}{|c|c|c|c|c|}
\hline \multirow{2}{*}{$\begin{array}{l}\text { Sources of } \\
\text { variation }\end{array}$} & \multirow{2}{*}{$\begin{array}{l}\text { Degrees of } \\
\text { freedom }\end{array}$} & \multicolumn{3}{|c|}{ F-values } \\
\hline & & Pupae & Ingested food & Egested food \\
\hline Time (covariate) & 1 & $1.80^{\mathrm{ns}}$ & $1.74^{\mathrm{ns}}$ & - \\
\hline Diet & 2 & $2.31^{\mathrm{ns}}$ & $0.17^{\mathrm{ns}}$ & - \\
\hline Feeding time $\mathrm{x}$ diet & 2 & $5.12 * *$ & $1.08^{\mathrm{ns}}$ & - \\
\hline Residual & 74 & - & - & - \\
\hline Feeding time & 1 & - & $1.74^{\mathrm{ns}}$ & - \\
\hline Diet & 2 & - & $14.26 * * *$ & - \\
\hline Residual & 74 & - & - & - \\
\hline Ingested food (covariate) & 1 & $46.06 * * *$ & & $190.23 * * *$ \\
\hline Diet & 2 & $0.62^{\mathrm{ns}}$ & & $7.81 * * *$ \\
\hline Ingested food $\mathrm{x}$ diet & 2 & $1.26^{\mathrm{ns}}$ & & $1.03^{\mathrm{ns}}$ \\
\hline Residual & 74 & - & - & - \\
\hline Ingested food & 1 & $45.74 * * *$ & & $190.07 * * *$ \\
\hline Diet & 2 & $7.92 * * *$ & & $49.75^{* * *}$ \\
\hline Residual & 74 & - & - & - \\
\hline
\end{tabular}

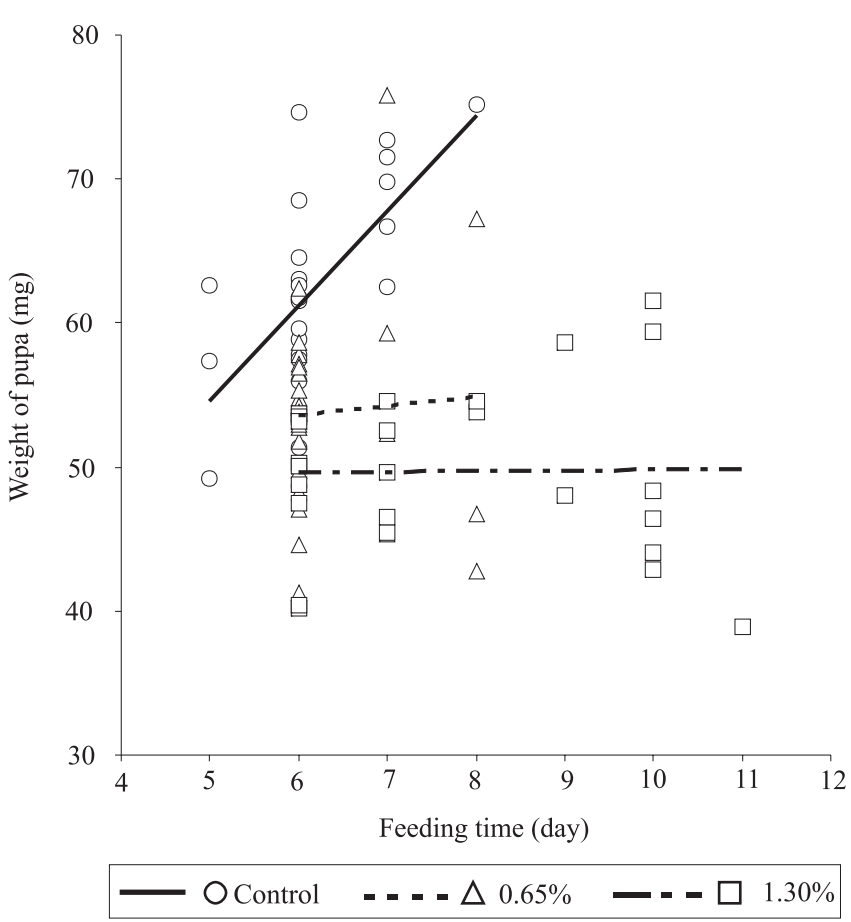

Figure 1. Feeding time (covariate) and pupa weight of A. gemmatalis larva, fed on diet control (without rutin addition) or containing rutin concentrations. 
pupa. Differently, when rutin was added to the diet, in spite of eating for longer time, larval weight remained almost stable.

The interaction among feeding time (covariate) and diet, regarding to its relationship with amount of ingested food (consumption) was not significant. Also, interactive effect of covariate amount of ingested food with diet was not observed in its relationships with pupal weight (efficiency in converting food into biomass) and egestion products (assimilation) (Table 2). Thus, the parallel line model could be used. Diet as main effect was significant in the relationship among feeding time and amount of ingested food. Larvae fed on the diet with rutin consumed less food as rutin content increased (Figure 2, inserted graph).

Pupal weight was strongly affected $(\mathrm{p} \leq 0.001)$ by the covariate amount of ingested food (Table 2). There was a positive relationship between them (Figure 3), showing that when the insect consumed more food, it grew larger. After adjustment of the pupal weight by the covariate, the effect of treatment remained significant. Pupae resulting from larvae fed on control-diet were heavier

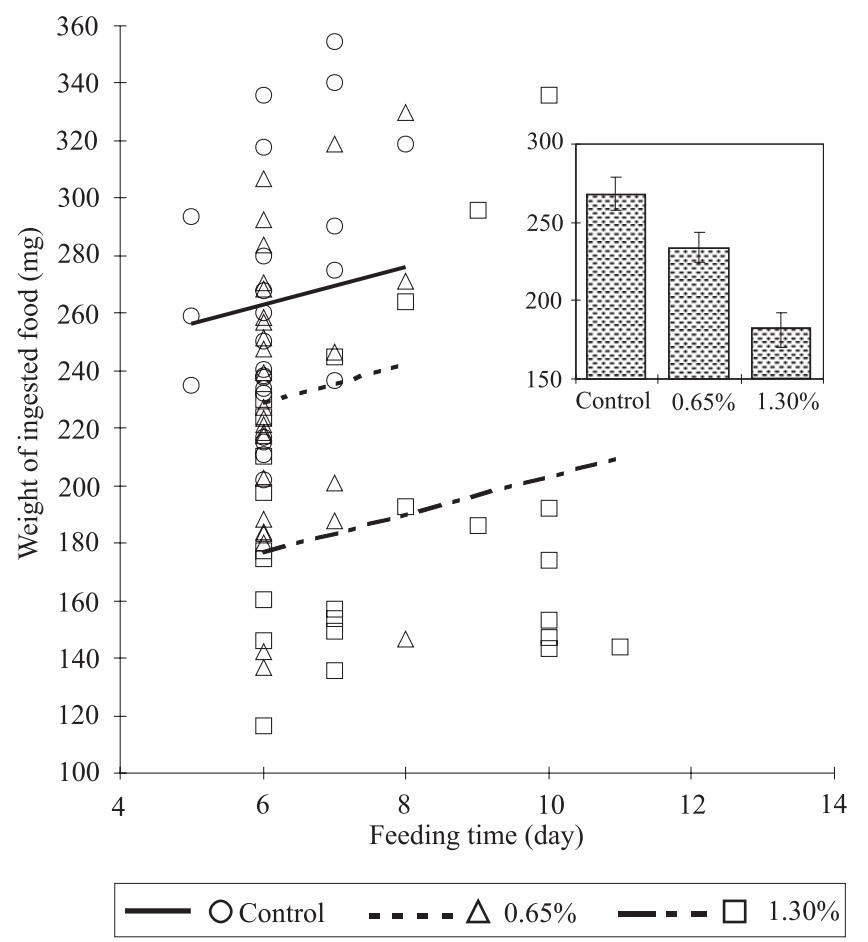

Figure 2. Feeding time (covariate) and weight of ingested food of A. gemmatalis larva, fed on diet control (without rutin addition) or containing rutin concentrations. Inserted graph shows the ANCOVA means. than those rutin diet-fed, independently of the consumption rate, indicating that the conversion of consumed food into biomass was negatively affected by the addition of rutin.

The diet, as main effect, and amount of ingested food (covariate) were highly significant (Table 2) in terms of its relationship with amount of egested products (Figure 4). Larvae fed on diet rutin-enriched eliminated larger amount of food by egestion when compared to those fed on plain diet, indicating that the assimilation of the food by A. gemmatalis decreased with increasing concentration of rutin.

Flavonoids are universal constituents of higher plants (Markham, 1989) and almost every plant species contains its own distinctive flavonoid profile. According to Hedin (1986), some pests have evolved mechanisms to detoxify, tolerate or utilize chemical compounds to their own favor. Consequently, studies have to be performed in order to indicate this compound as capable of increasing plant resistance to each insect-pest.

Rutin was a flavonoid identified on PI 227687 along with kaempferol and isorhamnetein glycosides

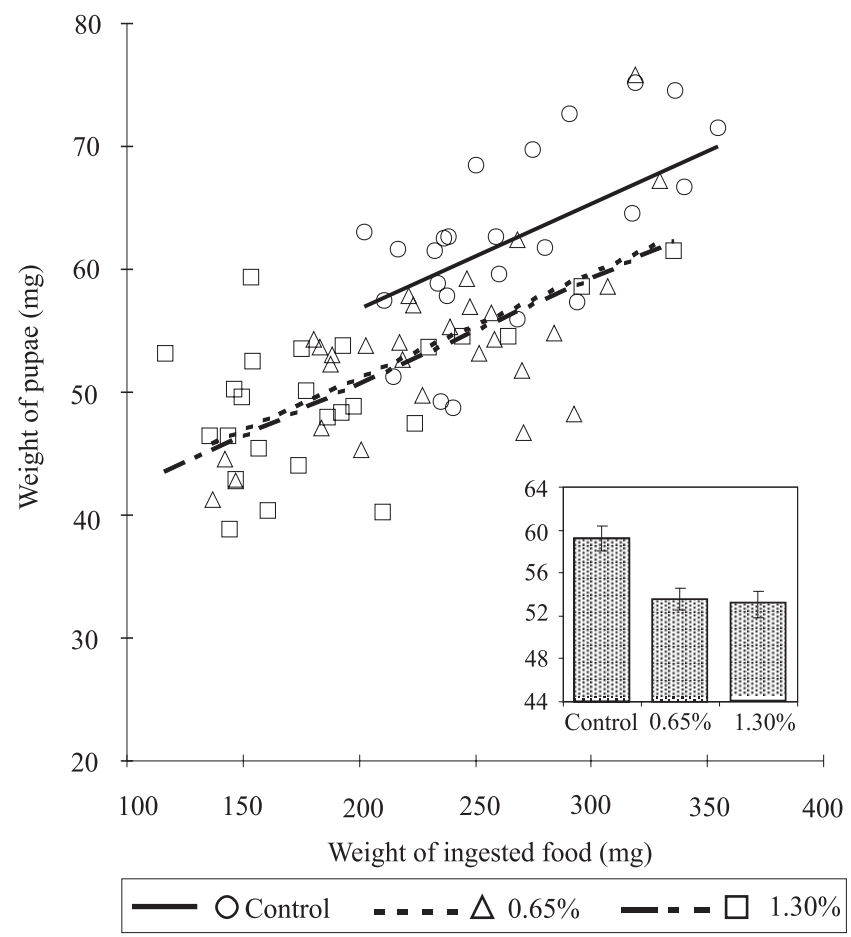

Figure 3. Weight of ingested food (covariate) and weight of pupae of A. gemmatalis, fed on diet control (without rutin addition) or containing rutin concentrations. Inserted graph shows the ANCOVA means. 
(Hoffmann-Campo, 1995). Rutin has been primarily mentioned as a feeding stimulant, at levels as high as $10 \%$ dry weight, to poliphagous insects as Schistocerca americana (Drury) (Bernays et al., 1991). However, it can be detrimental to insect growth, especially to certain lepidopteron as Helicoverpa (Heliothis) zea (Boddie) (Isman \& Duffey, 1982), M. sexta (Stamp \& Skrobola, 1993), H. virescens (Hoffmann-Campo, 1995), T. ni (Hoffmann-Campo et al., 2001).

A. gemmatalis is a leguminous specialist (Kogan \& Turnipseed, 1987) and considering that flavonoids are frequently used by monophagous and oligophagous insect to recognize their host plants (Harborne \& Grayer, 1993), it could be less affected by constitutive flavonoids, as rutin. However, contrarily as expected, many adverse effects were observed. Weight of pupa and amount of ingested food were strongly affected by adding rutin to artificial diet. Growth and consumption per unit of time, evaluated by ANCOVA, were inversely proportional to the concentration of flavonol on the diet, indicating that such compound acted as a feeding deterrent to the insect. This is a different behavior, compared to other

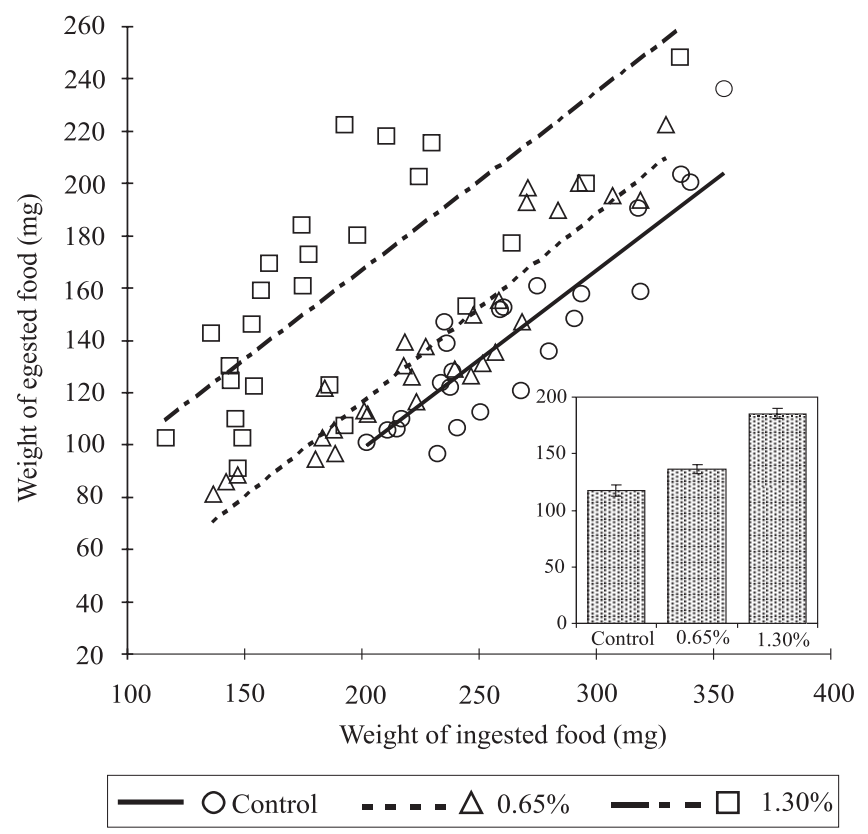

Figura 4. Relationship among weight of ingested food (covariate) and weight of egested food produced by larva of A. gemmatalis, fed on control diet (without rutin addition) or containing rutin concentrations. Inserted graph shows the ANCOVA means. lepidopterans, such as T. ni (Hoffmann-Campo et al., 2001), and M. sexta (Stamp \& Skrobola, 1993); these insects were unable to detect the toxic effect of the rutin before consumption and, once ingested, this compound adversely affected their physiology.

The A. gemmatalis rejection to PI 227687, which contains rutin, had been already observed in dual-choice test (Hoffmann-Campo et al., 1994). However, negative effects of rutin on $A$. gemmatalis growth were not only caused by feeding deterrence, since after adjustment of pupal weight by the amount of ingested food (covariate), the effect of diet remained significant. This indicates, as suggested by Horton \& Redak (1993), post-ingestive effect of rutin on A. gemmatalis growth.

Additionally, ANCOVA means indicate that they converted less food to body mass per unit of ingested food, demonstrated by the relationship between pupal weight and amount of ingested food (equivalent of Waldbauer`s ECI). Insects fed on diet containing rutin consumed less food and produced larger amount of egestion products per consumption unit, as compared to control-diet fed insects. Unexpectedly, the amount of egested food produced by A. gemmatalis, when analyzed by ANOVA, was not affected by diet. However, when the significant effect of amount of ingested food on the egested food was removed, by ANCOVA, diet effect became significant. This demonstrates that such analysis reduced the variances, increasing the power of test (Raubenheimer \& Simpson, 1992), allowing the detection of smaller differences between treatments.

Although the growth, consumption and efficiency in the conversion of the food to biomass were strongly affected in larvae from the third instar, mortality of A. gemmatalis fed on rutin-amended diet in such condition was less than $10 \%$. This experiment was set up by using third instar rutin-surviving individuals, as A. gemmatalis larvae have to be maintained aggregated on the insect diet in the previous instars to avoid high natural mortality, including in the control. However, newly hatched A. gemmatalis larvae are more sensitive to rutin than latter instars, as mortality in earlier stages is higher. Isman \& Duffey (1982) also observed that early instars of $\mathrm{H}$. zea were more susceptible to rutin toxicosis than the older ones. Older larvae are more capable of metabolizing the flavonoid.

Results obtained point out an alert to soybean breeders. When Hoffmann-Campo (1995) qualitatively examined the flavonoid profile of sixteen soybean 
genotypes, rutin was found in one resistant cultivar (IAC-100), one breeding line (BR82-12547) and two wild soybean genotypes (PI 227687 and PI 229358). This compound was not observed in 'BR-16' (Piubelli et al., 2005), 'Embrapa-1', 'Embrapa-4', 'IAS-5' and 'Davis' (Hoffmann-Campo, 1995). Consequently, this growth inhibitor of lepidopterans has been removed after successive breeding crosses and, as it is no longer identified in the soybean released cultivars, likely A. gemmatalis lost the ability of copying with this toxic compound, acting as a rutin-naïve insect.

The importance of chemical compounds in the natural (constitutive) resistance is recognized since the fifties, although their use has been little considered (Kogan, 1986). Identification of chemicals responsible for plant defense and their role in the interactions with insects can help the breeders in the development of cultivars resistant to pests (Hedin, 1986). In addition, flavonoids possess strong potential for metabolic engineering (Dixon \& Steele, 1999). Also, according to Cooper et al. (2004), the combination of traditional chemically based breeding programs and genetically engineered Bt-toxin based resistance has a potential to be much more sustainable and easily adopted than the usual higher dose/refuge strategies.

\section{Conclusion}

Rutin negatively affects $A$. gemmatalis growth by causing pre and post-ingestive effects.

\section{Acknowledgements}

To Universidade Estadual de Londrina, where part of this research was developed; to Drs. Décio Luiz Gazzoni, Flávio Moscardi and José Francisco Ferraz de Toledo (Embrapa Soja), for helpful comments to this work.

\section{References}

BERNAYS, E.A.; HOWARD, J.J.; CHAMPAGNE, D.; ESTESEN, B.J. Rutin: a phagostimulant for the polyphagous acridid Schistocerca americana. Entomologia Experimentalis et Applicata, v.60, p.1928, 1991.

BI, J.L.; FELTON, G.W.; MURPHY, J.B.; HOWLES, P.A.; DIXON, R.A.; LAMB, C.J. Do plant phenolics confer resistance to specialist and generalist insect herbivores? Journal of Agricultural and Food Chemistry, v.45, p.4500-4504, 1997.
COOPER, S.G.; DOUCHES, D.S.; GRAFIUS, E.J. Combining genetic engineering and traditional breeding to provide elevated resistance in potatoes to Colorado potato beetle. Entomologia Experimentalis et Applicata, v.112, p.37-46, 2004.

CORRÊA-FERREIRA, B.S.; DOMIT, L.A.; MORALES, L.; GUIMARÃES, R.C. Integrated soybean pest management in micro river basins in Brazil. Integrated Pest Management Reviews, v.5, p.75-80, 2000.

DIXON, R.A.; STEELE, C.L. Flavonoids and isoflavonoids - a gold mine for metabolic engineering. Trends in Plant Science, v.4, p.394400, 1999.

GAZZONI, D.L.; HÜLSMEYER, A.; HOFFMANN-CAMPO, C.B. Efeito de diferentes doses de rutina e de quercetina na biologia de Anticarsia gemmatalis Hübner, 1818 (Lep., Noctuidae). Pesquisa Agropecuária Brasileira, v.32, p.673-681, 1997.

HARBORNE, J.B.; GRAYER, R.J. Flavonoids and insects. In: HARBORNE, J.B. (Ed.). The flavonoids: advances in research since 1986. London: Chapman \& Hall, 1993. p.559-618.

HEDIN, P.A. Developing research trends in the chemistry of plant resistance to pests. In: GREEN, M.B.; HEDIN, P.A. (Ed.). Natural resistance of plants to pests: roles of allelochemicals. Washington: American Chemical Society, 1986. p.1-14. (Symposium series, 286).

HOFFMANN-CAMPO, C.B. Role of the flavonoids in the natural resistance of soybean to Helioths virescens (F.) and Trichoplusia ni (Hübner). 1995. 165p. Dissertation (Ph.D.) - The University of Reading, Reading.

HOFFMANN-CAMPO, C.B.; HARBORNE, J.B.; McCAFFERY, A.R. Pre-ingestive and post-ingestive effects of soya bean extracts and rutin on Trichoplusia ni growth. Entomologia Experimentalis et Applicata, v.98, p.181-194, 2001.

HOFFMANN-CAMPO, C.B.; MAZZARIN, R.M.; LUSTOSA, P.R. Mecanismos de resistência de genótipos de soja: teste de não preferência para Anticarsia gemmatalis Hübner, 1818 (Lepidoptera: Noctuidae). Pesquisa Agropecuária Brasileira, v.29, p.513-519, 1994.

HOFFMANN-CAMPO, C.B.; OLIVEIRA, E.B.; MOSCARDI, F. Criação massal da lagarta da soja Anticarsia gemmatalis. Londrina: Embrapa-CNPSo, 1985. 23p. (Embrapa-CNPSo. Documentos, 10).

HOFFMANN-CAMPO, C.B.; OLIVEIRA, L.J.; MOSCARDI, F.; GAZZONI, D.L.; CORRÊA-FERREIRA, B.S.; LORINI, I.A.; BORGES, M.; PANIZZI, A.R.; SOSA-GOMEZ, D.R.; CORSO, I.C. Integrated pest management in Brazil. In: MAREDIA, K.M.; DAKOUO, D.; MOTA-SANCHES, D. (Ed.). Integrated pest management in the global arena. Trowbridge: CABI Publishing: Cromwell Press, 2003. p.285-299.

HORTON, D.R.; REDAK, R.A. Further comments on analysis of covariance in insect dietary studies. Entomologia Experimentalis et Applicata, v.69, p.263-275, 1993.

ISMAN, M.B.; DUFFEY, S.S. Toxicity of tomato phenolic compounds to the fruit worm, Heliothis zea. Entomologia Experimentalis et Applicata, v.31, p.370-376, 1982.

KOGAN, M. Natural chemicals in plant resistance to insects. Iowa State Journal Research, v.60, p.501-527, 1986. 
KOGAN, M.; TURNIPSEED, S.G. Ecology and management of soybean arthropods. Annual Review of Entomology, v.32, p.507538, 1987.

KUBO, I.; HANKE, F.G. Chemical methods for isolating and identifying phytochemicals biologically active in insects. In: MILLER, J.R.; MILLER, T.A. ( Ed.). Insects-plant interactions. New York: Spring-Verlag, 1986. p.121-153.

MARKHAM, K.R. Flavones, flavonols and their glycosides. In: DEY, P.M.; HARBORNE, J.B. (Ed.). Methods in plant biochemistry. London: Academic Press, 1989. p.197-235.

MOSCARDI, F. Assessment of the application of baculoviruses for control of Lepidoptera. Annual Review of Entomology, v.44, p.257289, 1999.

OLIVEIRA, L.J.; HOFFMANN-CAMPO, C.B.; MAZZARIN, R.M. Aspectos biológicos e nutricionais de Anticarsia gemmatalis (Hübner, 1818) (Lepidoptera: Noctuidae) em diversos genótipos de soja. Anais da Sociedade Entomológica do Brasil, v.22, p.547-552, 1993.
PIUBELLI, G.C.; HOFFMANN-CAMPO, C.B.; MOSCARDI, F.; MIYAKUBO, S.H.; OLIVEIRA, M.C.N. de. Are chemical compounds important for soybean resistance to Anticarsia gemmatalis? Journal of Chemical Ecology, v.31, p.1509-1525, 2005.

RAUBENHEIMER, D.; SIMPSON, S.J. Analysis of covariance: an alternative to nutritional indices. Entomologia Experimentalis et Applicata, v.62, p.221-231, 1992.

RAUBENHEIMER, D.; SIMPSON, S.J. The analysis of nutrition budgets. Functional Ecology, v.8, p.783-791, 1994.

SAS INSTITUTE (Cary, Estados Unidos). SAS-STAT user's guide: release 6.12. Cary, 1996. 2v.

STAMP, N.E.; SKROBOLA, C.M. Failure to avoid rutin diets results in altered food utilization and reduced growth rate of Manduca sexta larvae. Entomologia Experimentalis et Applicata, v.68, p.127142, 1993.

$\overline{\text { Received on May 10, } 2005 \text { and accepted on May 24, } 2006}$ 